\title{
THE RESISTANCE TO IMPACT OF RAIL STEELS AT ELEVATED TEMPERATURES
}

\author{
By G. Willard Quick
}

\section{ABSTRACT}

Charpy impact tests were made in the temperature range $20^{\circ}$ to $700^{\circ} \mathrm{C}$. on $\checkmark$ notch specimens cut transversely and longitudinally from a medium manganese rail, and on longitudinal specimens cut from two standard rails, one cooled normally and the other cooled slowly after leaving the hot saw, two heat-treated rails and one untreated comparison rail, al d a commercial bar stock steel containing 0.60 per cent carbon. The energy absorbed in breaking the specimens from all these materials inceased as the temperature increased from $20^{\circ}$ to about $400^{\circ} \mathrm{C}$., then decreased to a minimum at about $600^{\circ} \mathrm{C}$., after which it increased rapidly to $700^{\circ} \mathrm{C}$. Tensile tests on the rail steels, reported previously, had shown a marked decrease in elongation and reduction of area for all of the rail steels between $400^{\circ}$ and $700^{\circ} \mathrm{C}$., with the minimum values at $550^{\circ}$ or $600^{\circ} \mathrm{C}$., but not for the bar stock. The tensile test had also shown somewhat higher ductility in the secondary brittle range for the slowly cooled rail and the heattreated rails than for the normally cooled and the untreated comparison rail, but the impact test did not distinguish between them. The path of the fractures in the impact specimens was transcrystalline at all temperatures. It is believed that the minimum values for impact strength occurring at $550^{\circ}$ or $600^{\circ} \mathrm{C}$. may be ascribed to the same phenomenon as the low ductility disclosed by the tensile tests at the same temperatures, namely, that of secondary brittleness rather than to the phenomenon of blue brittleness which some believe occurs at a higher temperature in dynamic tests than in tensile tests.

I. Introduction _........... 191

II. Materials tested and procedure

III. Results

1. Medium manganese rail 193

2. Rails cooled normally and cooled slowly after leaving the hot

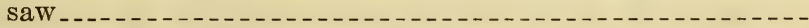

3. Bar stock, 0.60 per cent carbon steel

4. Heat-treated rails

5. Fractures under impact at high temperatures

IV. Discussion of results..

V. Summary

VI. Acknowledgments

\section{INTRODUCTION}

Tensile tests of rail steels at elevated temperatures ${ }^{12}$ have shown that certain rails, in addition to having low ductility in the wellknown blue brittle range in the neighborhood of $200^{\circ} \mathrm{C}$., have marked reduction in elongation and reduction of area in the temperature range from $400^{\circ}$ to $700^{\circ} \mathrm{C}$. This range of low ductility was called "the

1 John R. Freeman, jr., and G. Willard Quick, Tensile Properties of Rail and Other Steels at Elevated Temperatures. B. S. Jour. Research, vol. 4 (RP164), April, p. 549; 1930. Also, A. I. M. E. Iron and Steel Division, p. 225; 1930.

2 G. Willard Quick, Tensile Tests on Rail Steels at Elevated Temperatures. B. S. Jour. Research, vol.8 (RP408), p. 173; 1932. Also, A. I. M. E. Iron and Steel Division; 1932. 
secondary brittle range" and the phenomenon, "secondary brittleness."

The question naturally arises as to whether this property of the steels would be shown by impact tests performed in the same range of temperature. If so, the impact test, as suggested by Gillett ${ }^{3}$ would be a simpler and quicker method for the routine examination of steels at elevated temperature than the tensile test.

A number of investigators have reported results of impact tests on steels at elevated temperatures, in which the energy absorbed decreased with increase of temperature above $200^{\circ}$ or $300^{\circ} \mathrm{C}$. Langenberg ${ }^{4}$ performed Charpy impact tests on several steels at temperatures ranging from room temperature up to $1,000^{\circ} \mathrm{F}$. $\left(538^{\circ} \mathrm{C}\right.$.) . His results showed an increase in the energy absorbed in specimens tested in the range from room temperature to $200^{\circ}$ or $300^{\circ} \mathrm{C}$. and then a gradual decrease in the range, $300^{\circ}$ to $538^{\circ} \mathrm{C}$., the maximum temperature used. Greaves and Jones $^{5}$ reported Charpy impact tests on several steels at elevated temperatures up to $1,000^{\circ} \mathrm{C}$. Their results excepting those for "stainless" steel (12.37 per cent $\mathrm{Cr}$ ) were similar to Langenberg's in that the energy used in breaking the specimen decreased at temperature above $300^{\circ} \mathrm{C}$. to a minimum value at about $600^{\circ} \mathrm{C}$; ; then increased markedly to about $700^{\circ} \mathrm{C}$. At higher temperatures the values were again lower. For "stainless" steel, however, the values were approximately constant from $200^{\circ}$ to $600^{\circ} \mathrm{C}$. and then became somewhat higher. Monypenny ${ }^{6}$ has given results of Charpy impact tests at elevated temperatures for plain carbon and a number of alloy steels which are similar to those of Greaves and Jones.

Other investigators, ${ }^{789}$ recently have made impact tests on iron and steels at low temperatures and, in general, the results show that the impact resistance falls off rapidly as the temperature is reduced from $20^{\circ} \mathrm{C}$. to sub zero values. In the work of the previous investigators referred to, the tests at elevated temperatures were either not carried through the temperature range in which secondary brittleness has been shown by the tensile test, or else, when they were carried through this temperature range, the decrease in energy absorbed was ascribed to the phenomenon of blue brittleness.

Accordingly, in order to determine to what extent the changes in ductility as revealed by tensile tests would be duplicated by impact tests, a series of impact tests were made at elevated temperatures on a number of rail steels of which the tensile properties in the same range of temperature had already been determined.

3 H. W. Gillett, Trans. A. I. M. E. Iron and Steel Division, p. 270; 1930 . Discussion.

4 F. C. Langenberg, An Investigation of the Behavior of Certain Steels under Impact at Difierent Temperatures. J. Iron \& Steel Institute, Carnegie Scholarship Memoirs, vol. 12, p. 75; 1923. F. C. Langenberg, Investigation of the Influence of Temperature on the Charpy Impact Value of a Group of Steels of Varying Composition, Yearbook of Am. Iron \& Steel Institute, vol. 12, p. 349; 1923.

5 . H. Greaves and J. A. Jones, The Effect of Temperature on the Behavior of Iron and Steel in the Notched Bar Impact Test, J. Iron \& Steel Institute, vol. 112, No. 11, p. 123; 1925.

6 J. H. G. Monypenny, Stainless Iron and Steel. John Wiley \& Sons, Inc., N. Y., 1926.

$7 \mathrm{H}$. W. Russell, Effect of Low Temperatures on Metals and Alloys, Symposium on Effect of Temperature on the Properties of Metals, Joint Meeting of A. S. M. E. and A. S. T. M., Chicago, Ill.; June, 1931. 8 Robert Sergeson, Behavior of Some Irons and Steels Under Impact at Low Temperatures, Preprint No. 16, A. S. S. T., for Boston meeting; Sept. 21-25, 1931.

J. F. Cunningham and J. Gilchrist, Impact Characteristics of Steel Rails at Low Temperatures, Preprint No. 26, A. S. S. T., for Boston meeting; Sept. 21-25, 1931. 


\section{MATERIALS TESTED AND PROCEDURE}

The chemical compositions and types of steel from which the impact specimens were taken are given in Table 1. All of the steels except one were rail steels.

TABLE 1.-Materials tested

\begin{tabular}{|c|c|c|c|c|c|c|}
\hline \multirow{2}{*}{ Designation 1} & \multicolumn{5}{|c|}{ Chemical composition } & \multirow{2}{*}{ Remarks } \\
\hline & Carbon & $\underset{\text { nese }}{\text { Manga- }}$ & $\begin{array}{l}\text { Phos- } \\
\text { phorus }\end{array}$ & $\begin{array}{l}\text { Sul- } \\
\text { phur }\end{array}$ & Silicon & \\
\hline M2D. & $\begin{array}{c}\text { Per cent } \\
0.59\end{array}$ & $\begin{array}{l}\text { Per cent } \\
1.30\end{array}$ & $\begin{array}{l}\text { Per cent } \\
0.053\end{array}$ & $\begin{array}{l}\text { Per cent } \\
0.040\end{array}$ & $\begin{array}{c}\text { Per cent } \\
0.20\end{array}$ & \multirow{2}{*}{ 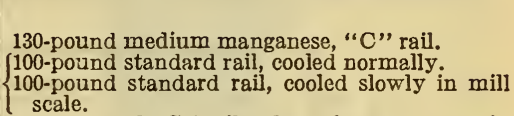 } \\
\hline AL1. & .69 & .70 & .023 & .027 & .14 & \\
\hline H1 ... & .73 & .60 & .026 & .050 & .25 & $\begin{array}{l}\text { Heat-treated "C" rail. Quenched } 30 \text { seconds in } \\
\text { water, in furnace at } 510^{\circ} \mathrm{C} \text {., } 11 / 2 \text { hours, then air } \\
\text { cooled. }\end{array}$ \\
\hline $\mathrm{H} 2 \ldots$ & .74 & .62 & .043 & .063 & .31 & $\begin{array}{l}\text { Heat-treated "C" rail. Quenched } 15 \text { seconds in } \\
\text { water; in furnace at } 510^{\circ} \text { C., } 11 / 2 \text { hours, then air } \\
\text { cooled. }\end{array}$ \\
\hline $\mathrm{H} 3$ & .60 & .66 & $\begin{array}{l}.040 \\
.050\end{array}$ & .033 & .32 & $\begin{array}{l}\text { Comparison "C" rail; not heat treated. } \\
3 / 4 \text { by } 21 / 4 \text { inch bar stock. }\end{array}$ \\
\hline
\end{tabular}

1 The designation of the material is the same as that used in the tensile tests reported previously, see footnotes 1 and $2, \mathrm{p} .191$.

The impact tests were carried out on an American-made Charpy machine of 160 foot-pounds capacity. The specimens were $1 \mathrm{~cm}$ square. in cross section, and had a $45^{\circ}$ notch 0.079 inch deep, with a radius of 0.01 inch at the bottom. From 10 to 20 specimens were used for determining each of the curves given to show the variation in impact resistance with increase in temperature. The notches were cut in all of the specimens of a series at one time on a milling machine while the specimens were clamped side by side in a jig. In conducting the test, the specimens were heated slowly in an electric resistance furnace to the desired temperature which was determined by means of a hase metal thermocouple and portable potentiometer. The bead or hot junction of the thermocouple was located in the notch of the specimen. After holding for 15 minutes at the desired temperature, the specimen was transferred with insulated tongs to the machine and broken. The time required for the transfer was about three seconds, and preliminary tests had shown that the maximum temperature drop from the time of removal from the furnace until the specimen was broken was not more than $5^{\circ} \mathrm{C}$. No correction was made for this change in temperature since the significance of the results would not be appreciably affected by so small a change.

\section{RESULTS}

\section{MEDIUM MANGANESE RAIL}

Tests were made on specimens taken both longitudinally and transversely from rail M2D. The longitudinal specimens were taken from either side of the head. One set of transverse specimens was taken across the top of the head with the notch on the portion just under the tread while the second series of transverse specimens was cut from the middle of the head and the notch was cut on the side toward the tread of the rail. 
The results of the impact tests are plotted in Figure 1, together with the results of tensile tests which have been reported previously. ${ }^{10}$ The curve for the Charpy results on longitudinal samples rose from room temperature to a maximum at about $350^{\circ} \mathrm{C}$. and then fell to a minimum at a temperature of $550^{\circ}$ or $600^{\circ} \mathrm{C}$., after which it rose steeply to $750^{\circ}$ C., the maximum temperature used. The shape of the curve was similar to that of the curves summarizing the values for elongation and reduction of area determined in tensile tests in the secondary brittle range. The results of the tests on the two sets of transverse specimens also are plotted in Figure 1. These curves were similar to those for the longitudinal specimens except that the energy absorbed throughout the temperature range was less. The transverse

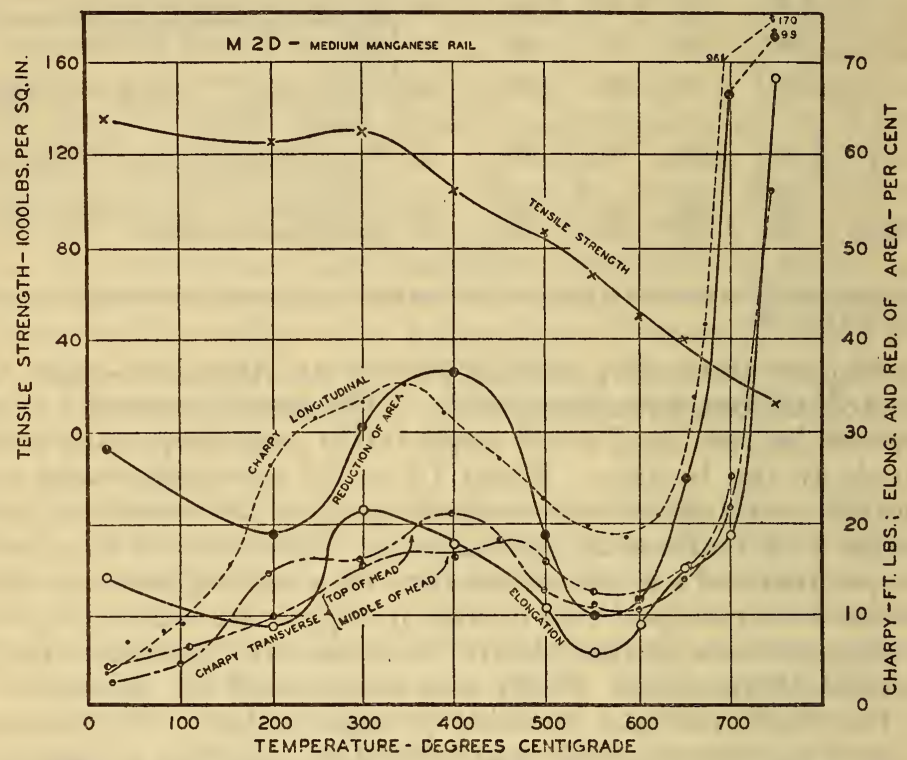

FIGURE 1.-Results of Charpy impact tests of specimens taken both longitudinally and transversely, and tensile tests of specimens taken longitudinally from rail M2D

Transverse Charpy specimens were from both the top and middle of the head.

specimens from the top of the rail absorbed more energy between $150^{\circ}$ and $450^{\circ} \mathrm{C}$. than those from the middle of the head, but from $450^{\circ}$ to $700^{\circ} \mathrm{C}$. the specimens from the middle of the rail absorbed slightly more energy. The fractured longitudinal specimens and the transverse specimens taken just under the head of the rail are shown in Figure 2. The longitudinal specimens tested above $670^{\circ} \mathrm{C}$. did not break completely apart, but bent over the tup sufficiently to permit passage through the supports of the machine. The unbroken specimens formed an angle of about $55^{\circ}$. Although the values for the energy absorbed by the specimens that did not break completely are not strictly comparable with the values obtained for the completely broken specimens, the results for both have been plotted in the figures. Any errors introduced in the values on the partly broken 


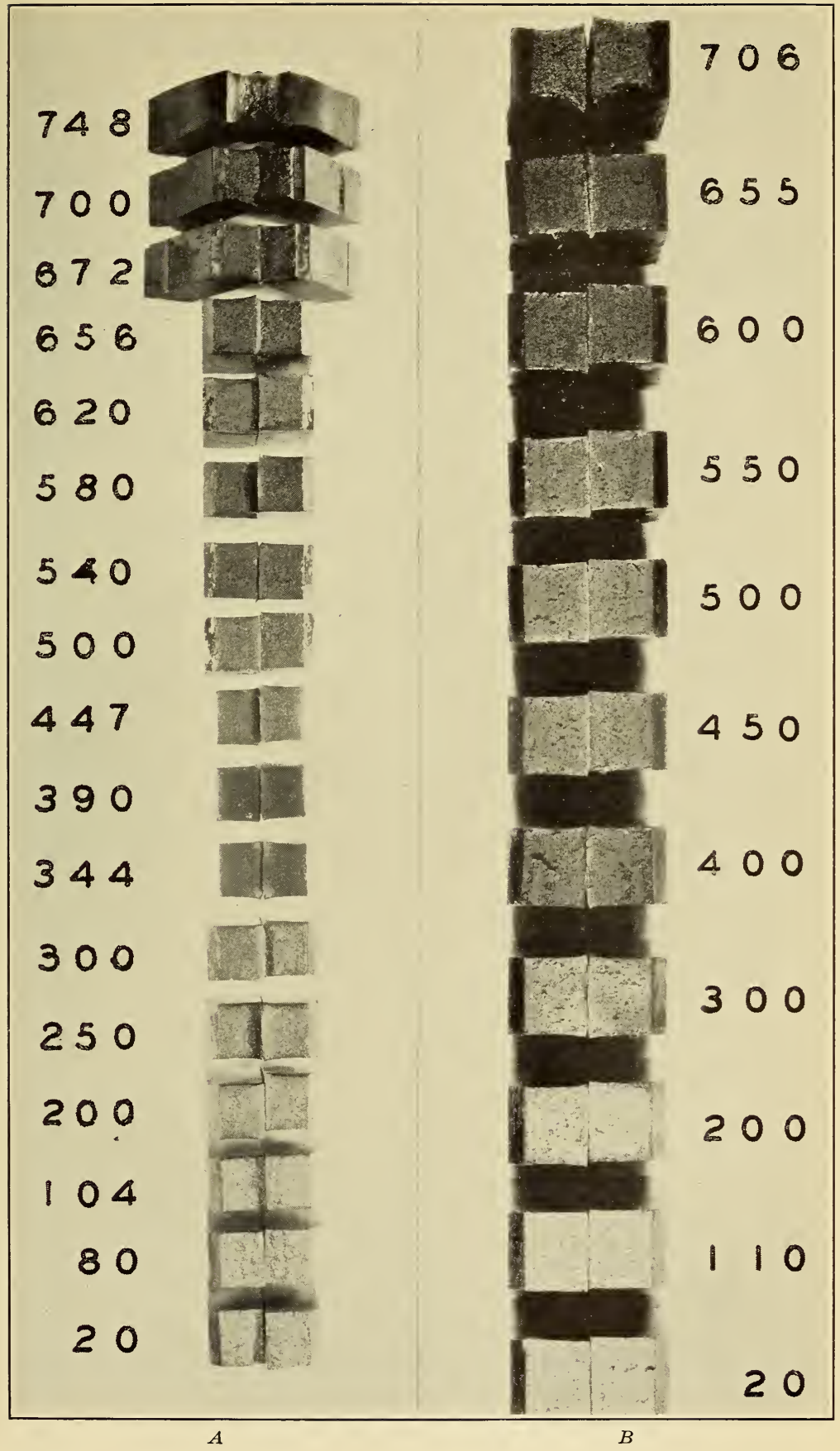

FIGURE 2.-Fractured Charpy impact specimens showing the temperature in ${ }^{\circ} \mathrm{C}$. at which they were broken

$A$, Specimens taken longitudinally; $B$, specimens taken transversely. 
specimens would modify the results only very slightly because the temperatures at which incomplete fractures occurred were above the range of secondary brittleness.

\section{RAILS COOLED NORMALLY AND COOLED SLOWLY AFTER LEAVING THE HOT SAW}

The results of impact and tensile tests at elevated temperatures on rail AL1 cooled normally and rail AL2 cooled slowly are given in Figure 3. The Charpy impact results on longitudinal specimens showed secondary brittleness for both AL1 and AL2 to about the same degree, whereas the results of the tensile tests showed that the elongation and reduction of area were modified by slow cooling. Although the Charpy impact test showed secondary brittleness in

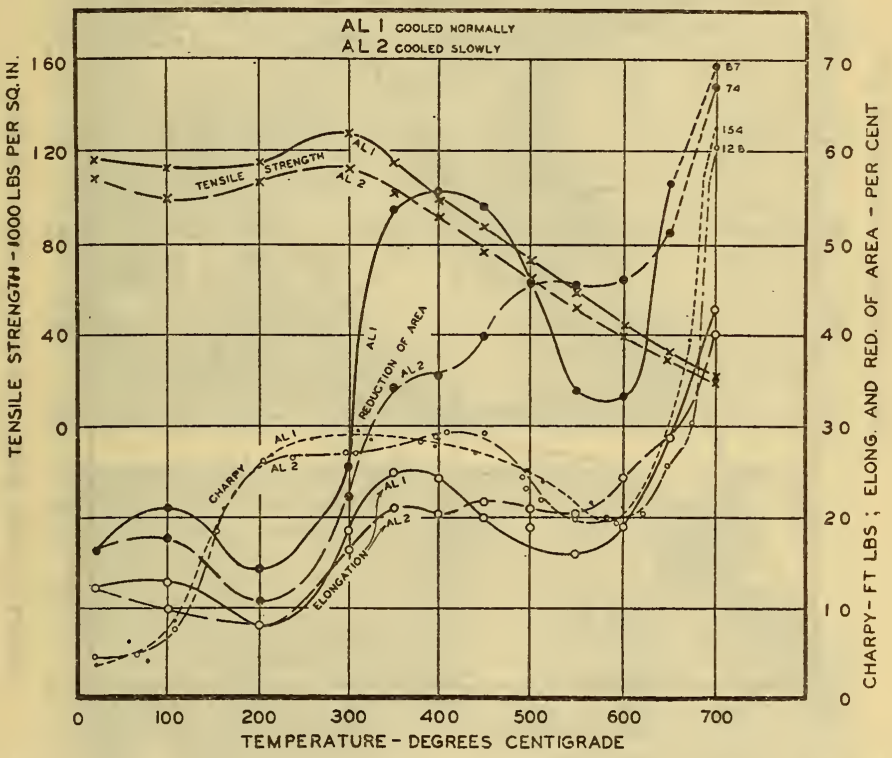

FIgURE 3.-Results of Charpy impact tests and tensile tests of specimens from new rails of the same heat

AL1 cooled normally and AL2 cooled slowly in mill scale from the hot saw.

the rails, it did not distinguish between the two which had been cooled at different rates after leaving the hot saw.

\section{BAR STOCK, 0.60 PER CENT CARBON STEEL}

This material in the annealed condition was reported in a previous paper ${ }^{11}$ to show no secondary brittleness in tensile tests at elevated temperature. These results along with those of the impact tests of the material in both the annealed and "as received" conditions are shown in Figure 4 . It will be noted that marked secondary brittleness was indicated by the impact test for the steel in both the annealed and "as received" conditions. In this case, the dynamic test showed 
decreased ductility in the secondary brittle range whereas the tensile test did not.

\section{HEAT-TREATED RAILS}

Impact tests at elevated temperatures were made on specimens cut from two heat-treated " $\mathrm{C}$ " rails and a comparison rail made in the usual manner. The heat treatments were as follows: Rail H1, quenched from about $750^{\circ}$ C., for 30 seconds, in water.

Rail $\mathrm{H} 2$, quenched from about $750^{\circ} \mathrm{C}$., for 15 seconds, in water.

Both of the above rails after quenching were held one and one-half hours in a furnace at $510^{\circ} \mathrm{C}$., then air cooled.

The tensile results, which have been reported previously ${ }^{12}$ showed that the untreated rail had marked secondary-brittleness; the rail

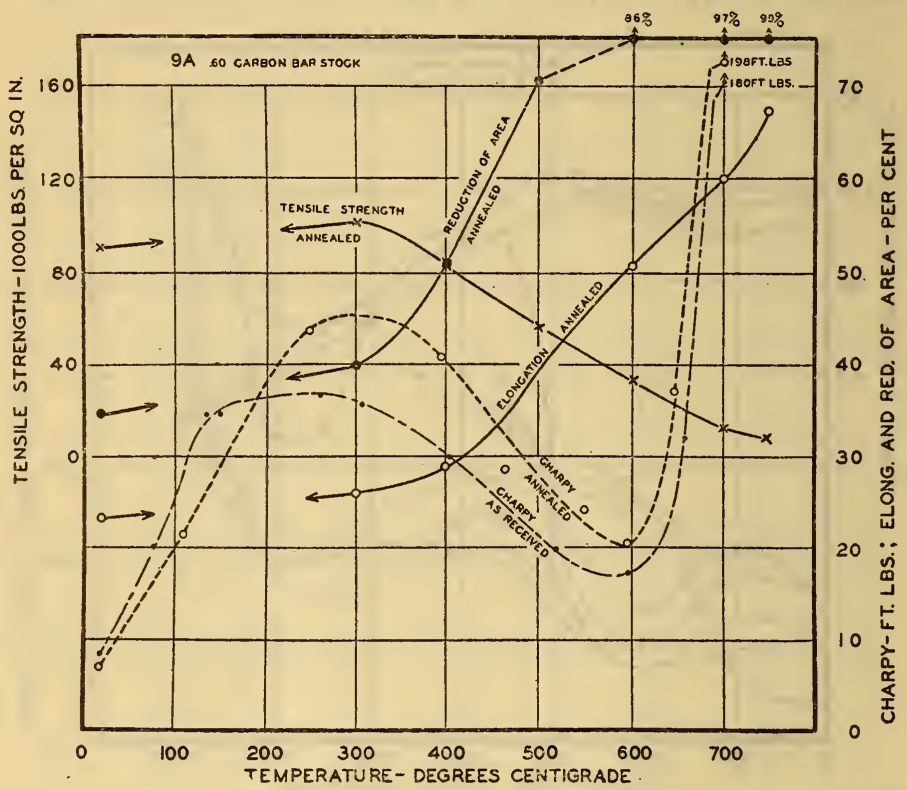

FIGURE 4.-Results of Charpy impact tests in the "as received" and annealed conditions, and tensile tests in the annealed condition of specimens from 0.60 per cent carbon bar stock, $9 \mathrm{~A}$

quenched for 30 seconds was somewhat less brittle; and the rail quenched for 15 seconds showed the greatest improvement in ductility in the secondary brittle range. Secondary brittleness in all three rails was shown by the results of the impact tests, Figure 5 . The untreated rail, $\mathrm{H} 3$, absorbed less energy in the temperature range, $200^{\circ}$ to $400^{\circ} \mathrm{C}$., than the heat-treated rails, and less than $\mathrm{H} 2$ but more than $\mathrm{H} 1$ in the range, $450^{\circ}$ to $600^{\circ} \mathrm{C}$. Rail $\mathrm{H} 2$ showed a peculiar irregularity between $250^{\circ}$ and $350^{\circ} \mathrm{C}$. In general, the results of the impact tests on these rails were similar to those shown in Figure 3 for normally and slowly cooled rails in that the effect of the rate of cooling did not manifest itself as markedly in the impact resistance as in the tensile properties. 


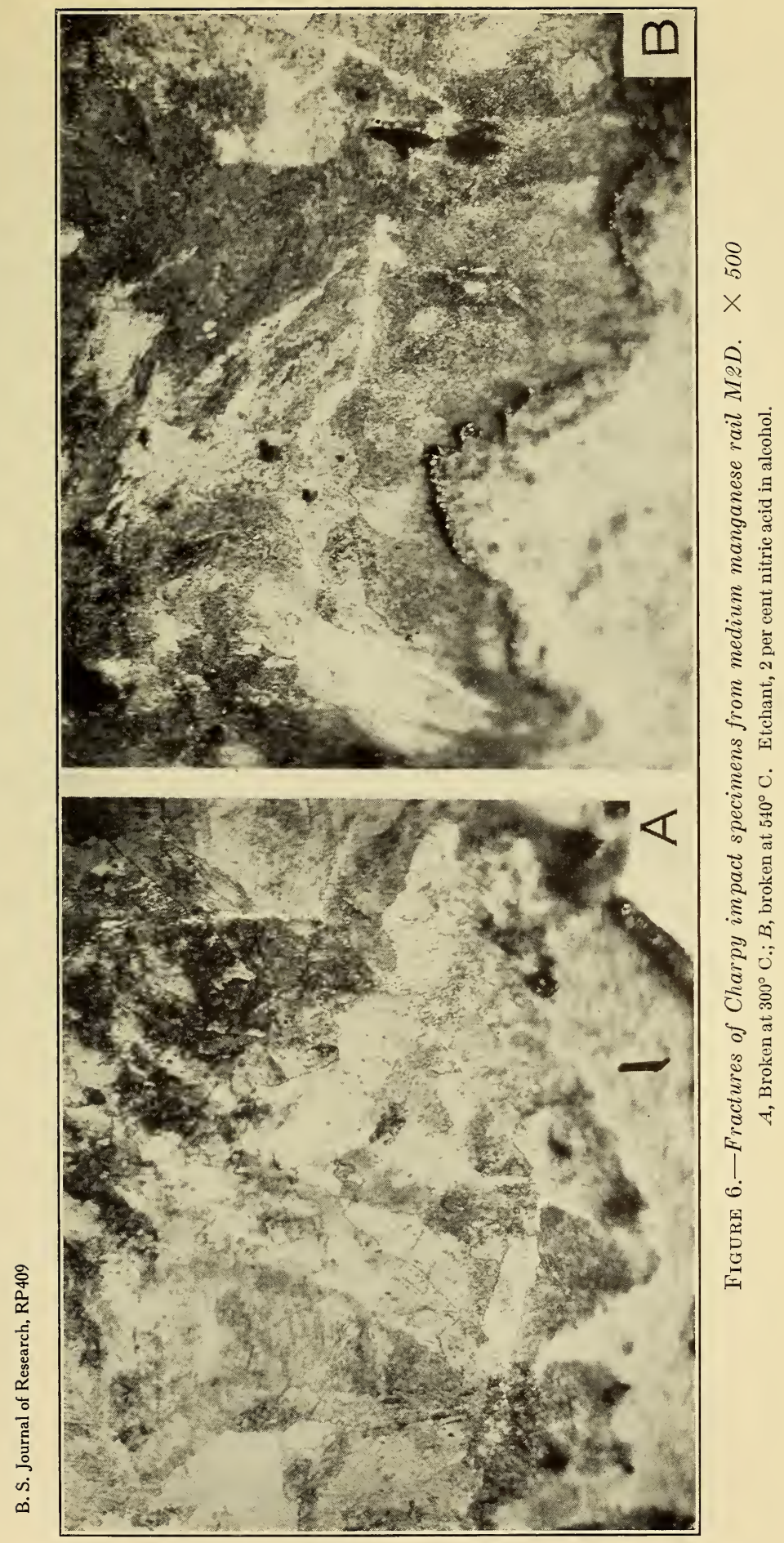




\section{FRACTURES UNDER IMPACT AT HIGH TEMPERATURES}

Metallographic examinations were made to determine whether the path of the fracture was transcrystalline or intercrystalline. To preserve the face of the fracture during the polishing operation a heavy coating of copper was electroplated on the specimens. To obtain good adherence of the copper at the extreme edges of the fracture, it was necessary to remove all traces of the oxide film formed during the impact test without altering the surface of the steel. This was done by making the specimen the cathode in a 5 per cent (by weight) solution of sulphuric acid while a current of about 100 milliamperes at about 4 volts was applied for two or three minutes. A plate of high silicon cast iron formed the anode of the cell. The plated specimens were split longitudinally in a plane perpendicular to the notch and the cut surface was polished for examination. The

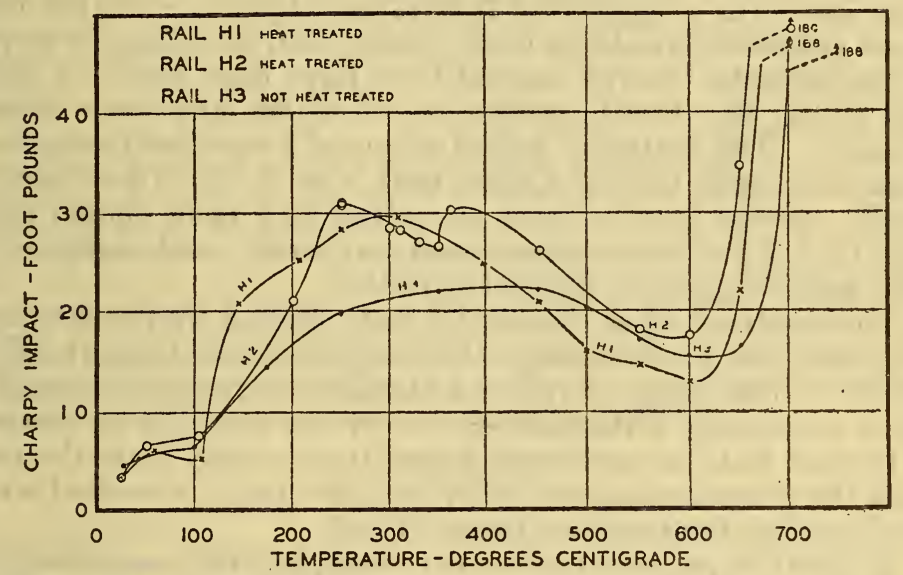

FIGURE 5.-Results of Charpy impact tests of specimens from heat-treated rails $H 1$ and $H 2$, and rail $H 3$, not heat treated

Rail H1, quenched 30 seconds in water.

Rail H2, quenched 15 seconds in water.

Both rails after quenching were held one and one-half hours in a furnace at $510^{\circ} \mathrm{C} .\left(950^{\circ} \mathrm{F}.\right)$, than air cooled.

fractures were found to be transcrystalline for all temperatures of test from $20^{\circ} \mathrm{C}$. to the critical temperature. Those heated above the Ac range had recrystallized. Micrographs of two of the fractured specimens from medium manganese rail M2D are shown in Figure 6.

\section{DISCUSSION OF RESULTS}

The results of Charpy impact tests on rail steels at elevated temperature were in agreement with those given by other investigators for various carbon steels.

The energy absorbed by the notched specimen when broken under impact increased from room temperature to $300^{\circ}$ or $400^{\circ} \mathrm{C}$., showed no decrease at the "blue-brittle" temperature, and then gradually decreased as the temperature of test was raised to about $600^{\circ} \mathrm{C}$. From $600^{\circ}$ to $700^{\circ} \mathrm{C}$. there was a sharp and marked increase of several hundred per cent. A few tests at higher temperatures have shown that the energy absorbed again decreased. It appears that 
this decrease does not represent brittleness, but should be attributed rather to the increased plasticity and decreased tensile strength of the steel at the higher temperatures. It has been suggested by some investigators ${ }^{13}$ that blue brittleness, manifested in tensile tests at about $200^{\circ} \mathrm{C}$., extends to higher temperatures in dynamic tests and is represented by the low impact values at $500^{\circ}$ and $600^{\circ} \mathrm{C}$. It is seen from the results of tests in this paper that the low impact resistance in the temperature range $400^{\circ}$ to $700^{\circ} \mathrm{C}$., corresponds to the low values of elongation and reduction of area from tensile tests in the secondary brittle temperature range. It would appear reasonable that the low values in both tests are properly to be regarded as manifestations of the same phenomenon.

\section{SUMMARY}

1. In line with a suggestion that impact tests at elevated tempera-' tures on rail steels would be both quicker and more simple to perform than tensile tests, Charpy impact tests have been made on specimens of rail steels, the tensile properties of which had been determined previously. The materials tested included a medium manganese rail; two standard rails from the same heat, one of which had been cooled normally on the hot bed and the other had been cooled slowly; a sample of 0.6 per cent carbon steel bar stock; and samples of heat treated and comparison untreated rails.

2 . The results of all of the impact tests showed that at temperatures of $500^{\circ}$ and $600^{\circ} \mathrm{C}$. the energy absorbed was lower than at either $400^{\circ}$ or $700^{\circ} \mathrm{C}$. This range of reduced ductility corresponds closely to the range of secondary brittleness shown by low ductility in tensile tests.

3. Impact tests on specimens taken transversely from the rails also showed the phenomenon markedly but the energy absorbed was lower throughout the temperature range of test.

4. In the 0.60 per cent carbon bar stock, in which secondary brittleness was not shown in tensile tests, marked decrease in energy absorbed in the secondary brittle range was shown in the impact tests. This was true for the material in both the "as received" and the annealed condition:

5. A reduction in the energy absorbed at $500^{\circ}$ and $600^{\circ} \mathrm{C}$. was shown by impact tests on heat-treated rails and a comparison normal rail. The impact tests did not discriminate as closely between the heat treatments as well as previously reported tensile tests on the rails had done.

6. Longitudinal specimens tested in impact at temperatures above $660^{\circ} \mathrm{C}$. did not fracture completely.

7. The fractures of the impact specimens were found to be transcrystalline throughout the range of temperature of the tests.

\section{ACKNOWLEDGMENTS}

The author is indebted to several members of the staff of the Bureau of Standards, particularly H. S. Rawdon and W. H. Swanger for valuable suggestions in the preparation of the manuscript, and to P. Devaney, who carefully machined all of the test specimens.

Washington, December 28, 1931. 